\title{
Reduction of Odor Nuisance from the Composting Process
}

\author{
Monika Gałwa-Widera' ${ }^{*}$, Anna Kwarciak-Kozłowska ${ }^{1}$ \\ 1 Faculty of Infrastructure and Environment, Institute of Environmental Engineering, Czestochowa University \\ of Technology, ul. Brzeźnicka 60a, Czestochowa, Poland \\ * Corresponding author's e-mail: mwidera@is.pcz.czest.pl
}

\begin{abstract}
Biofiltration is the biological degradation of gaseous pollutants and is one methods of deodorizing disruptive malodorous gases. Micro-organisms play a central role in this process. As a result of their work, non-toxic compounds are produced. Biofiltration belongs to the methods that are low to non-waste producing. This is an alternative to classical methods used so far. The research on the improvement of process parameters and increasing its efficiency is being carried out. The applied solutions referred to above still constitute unresolved problem and for this reason are seldom used. This article presents a mechanism for biofiltration of odorous gases. The article is devoted to the mechanism of malodorous gases biofiltration on the basis of a study carried out on the half-scale support.
\end{abstract}

Keywords: biomass, composting, industry, sewage sludge, odor

\section{INTRODUCTION}

Perceiving aromas is an individual matter. The same smell can trigger different reactions, depending, for example, on the smell and sensitivity of the individual. The determination of unambiguous criteria for odor nuisance is extremely difficult, but there is no doubt that odors can have a negative impact on human health. Prolonged exposure to odor nuisance may cause depression, fatigue, respiratory problems, headaches, nausea, irritation of the eyes and throat.

The Ministry of Environment made several attempts to regulate the problem of odor nuisance. It resulted, among others, in introducing the Regulation on the reference values for fragrances in the air and methods for assessing the aroma of air quality on the basis of art. 222 of the Act of 27 April 2001 - Environmental Protection Law and draft assumptions of the Act on preventing odor nuisance, as well as review of applicable legal provisions.

The work on the legal regulation of odor nuisance has been undertaken for many years both in the country and the entire European Union. The multifaceted nature of this problem means that up to now there has been no uniform EU legislation in this area, in the form of a directive or guidelines. However, the problem itself still exists.

Waste composting is a method based on natural biochemical reactions in the soil (mineralization, humification), artificially intensified

conditions that ensure the ability to control these processes. Composting takes place with the participation of numerous groups of microorganisms. It is an aerobic, biothermal process that occurs in two phases:

- Phase I - thermophilic composting, also known as intensive composting or phase composting. At high temperature;

- Phase II - mesophilic composting, also known as maturation.

Phase run time depends on the composition of the composted biomass and the technology used.

Oxygen mineralization is an exothermic process, and the intensity of decomposition depends on the susceptibility of compounds to decomposition. Fats, most sugars (including starch) and proteins are very easily decomposed; in turn, decomposition of hemicellulose and cellulose is more difficult. Lignin and proteins from the group of scleroproteids (e.g. keratin) are very resistant to 
decomposition. In the intensive composting phase, the temperature can exceed $70^{\circ} \mathrm{C}$. This phase is of key importance for hygienization processes.

The odorants produced during the waste composting process are one of the main sources of emissions of pollutants into the air, including odorogenic substances. The most important of these pollutants are volatile organic compounds, sulfur and nitrogen compounds. They are characterized not only by odor nuisance, but also by the level of toxicity and significant harm to the environment [1]. Using this method, the formation of aromatic compounds occurs at all technological stages of waste disposal. Firstly, the odors from biomass directed to composting are generated, and the floating odor is characteristic of municipal waste. After initiating the composting process, microorganisms start their activity. In the first phase of the process, sewage smells and odors resulting from oxygen-anoxic transformations are emitted. It is a mesophilic phase that usually lasts for several days [2]. In the next phase, i.e. thermophilic, there is a rapid decomposition of organic matter. Then, the strongly smelling substances arise. Particularly intense smell of waste gases during composting occurs when the process temperature exceeds $60^{\circ} \mathrm{C}$ [3]. The individual phases of the process are related to the changes in the composition of gases, i.e. the quality and quantity of odorants contained in them. The concentration of odors in the gas generated during composting often exceeds $180,000 \mathrm{ou} / \mathrm{m}^{3}$. the most odorous compounds and simultaneously the most unpleasant ones include ammonia $\left(\mathrm{NH}_{3}\right)$ and hydrogen sulphide $\left(\mathrm{H}_{2} \mathrm{~S}\right)$. Emissions can be relatively easily reduced by appropriate process management (aeration, flip transfer, biofuel).

\section{Biofitration - a deodorization method}

Absorption, adsorption and condensation methods are mainly used for the removal of odorants from waste gases,. Choosing the right odor removal technique depends on many factors, such as the type of emission source or the properties of the emitted gases and their impurities.

An interesting alternative to physical and chemical methods are the biological processes, which are practically waste-free methods [1,3]. In biological methods, impurities are absorbed in the liquid phase and then biodegraded by microorganisms. This leads not only to gas purification, but also to cleaning the sorption material by itself [5].
Odor substances, formed at various stages of the technological process, can be effectively removed using biological methods. Particularly good elimination effects by biofiltration are obtained with respect to hydrogen sulphide. Biological oxidation of $\mathrm{H}_{2} \mathrm{~S}$ to elemental sulfur and water vapor occurs owing to a specialized group of microorganisms from the Thiobacillus family [3, 4].

These microorganisms use carbondioxide from biogas as a carbon source. The product of changes is elemental sulfur and sulphates. In practice, one can meet different types of biofilters in terms of construction, as well as fillings used in them, or additions to affect the efficiency of gas cleaning.

The devices must provide:

- meeting the basic conditions of mass transfer across the gas-liquid boundary (including the necessary surface and phase contact time, gas flow rate),

- keeping unchanging or variable in a narrow range of system parameters, set at levels that favor the growth of microorganisms, e.g.

- temperature - for most enzymes, the optimal level is in the range of $30-40^{\circ} \mathrm{C}$,

- humidity - optimum of approx. 50\% relative humidity (at least $30 \%$, acceptable short-term drying),

- $\mathrm{pH}$ - optimal level for most enzymes: $\mathrm{pH}=5-7$,

- concentration of biogenic elements and the proportions between them - for heterotrophic bacteria: $\mathrm{C}: \mathrm{N}: \mathrm{P}=100: 5: 1$,

- no poisons (e.g. heavy metal ions, detergents, cyanides or strong oxidants).

In biofilters, the carrier of the biofilm is natural organic materials, e.g. compost, peat, tree bark, straw, fluffed soil. A linear gas velocity of $0.03-0.1 \mathrm{~m} / \mathrm{s}$ (volume flow relative to the entire bed cross-sectional area) is usually used.

Another equally important element is the appropriate selection of the filtration material, which is to ensure high porosity (e.g. peat: $90 \%$, compost: $40-60 \%$ ) and a large specific surface area and, for economic reasons, the lowest flow resistance $[1,6]$. The physical and chemical conditions in the deposit affect the efficiency of the biofiltration process, including the condition and amount of microorganisms responsible for the gas cleaning process. It is therefore important to provide an optimal environment for their development. The effects of a given factor may vary, depending on its type and intensity, as well as on 
the species characteristics of the organism. The most important factors affecting the growth, reproduction, survival and metabolic activity of microorganisms include: temperature, hydrogen ion concentration, redox potential, water content in the environment, food availability and harmful chemicals. Temperature has a direct impact on the life processes of microorganisms [7]. The optimal temperature is $25-40^{\circ} \mathrm{C}$. In various temperature ranges, different micro-organisms exhibit their activity, so the quality of the gas to be treated, the type of compounds to be removed and the temperature of the bed to be optimized should be taken into consideration. As a result of microbial activity, large amounts of heat can be released, causing the temperature in the filtration bed to rise. In winter, the temperature inside the biofilters can be higher than the ambient temperature by $10-20^{\circ} \mathrm{C}[1,8,9]$. An equally important factor affecting not only the viability of organisms, but also the absorption of pollutants from the gas phase is humidity. For this reason, the gases are pre-moistened before being sent to the filter bed $[1,11,12]$. The life activity of microorganisms is strongly dependent on the concentration of hydrogen ions. The neutral reaction is optimal; however, during biofiltration of gases containing, for example, hydrogen sulphide, acidification of the substrate may occur, which can reduce bacterial activity $[1,10]$. During the flow of gas through the filter material layer, the contaminants from the gas phase spread to the active layer covered with biofilm of microorganisms. In the liquid phase, in which dissolved pollutants, microorganisms and enzymes are found, the gaseous pollutants are decomposed to form $\mathrm{CO}_{2}, \mathrm{H}_{2} \mathrm{O}$ and biomass. Owing to the biomass which is rich in nutrients, microorganisms develop and consequently, "process" more pollutants.Bacteria, as well as actinomyces, fungi and micotrophic algae, such as cyanobacteria, take part in the mineralization of organic pollutants. The biological degradation of pollutants absorbed in the biovaration is the self-regeneration of the filtration material, on the surface of which there is a biofilm $[13,14,15]$.

\section{METHODOLOGY OF CONDUCTED PILOT STUDIES}

\section{Characteristics of the composting process}

The research was of pilot nature and was carried out on a semi-technical scale. The main focus was on the elimination of the odors of inorganic origin (hydrogen sulphide and ammonia) generated during the composting of municipal waste. The composting process was carried out in a commercial composting plant operating in a container system. The bioreactor consisted of 7 modules, each chamber with a working capacity of approx. $25 \mathrm{~m}^{3}$. The filling of the reaction chambers in the initial phase was about $80 \%$. The bioreactor system is fully controlled, thermally insulated as well as enables aerating and spraying the compost mixture. The course of the process was monitored in terms of temperature, the amount of air supplied, $\mathrm{pH}$ and humidity. The level of aeration was dependent on the phase and was on average $4.8 \mathrm{dm}^{3} / \mathrm{min}$. The composting process was carried out in a continuous system. All its parameters were maintained in accordance with the requirements included in the guidelines on requirements for the composting, fermentation and mechanicalbiological treatment processes of the Ministry of the Environment [16]. Table 1 presents the values of process parameters.

\section{The values in the table are the average of 5 measurements performed once a day.}

The compost mixture comprised: the organic fraction of municipal waste, the kitchen waste from a selective collection, and green waste from the urban area. The structure-forming material was made of wood. The average $\mathrm{C} / \mathrm{N}$ ratio was 27: 1 .

Table 1. Parameters for conducting the composting and biofiltration process

\begin{tabular}{|c|l|c|c|}
\hline \multicolumn{1}{|c|}{ Parameter } & Composting chamber & Biofilter chamber \\
\hline 1 & Humidity & $55-58 \%$ & $65-70 \%$ \\
\hline 2 & $\mathrm{pH}$ & 6,5 & 7,2 \\
\hline 3 & $\mathrm{C} / \mathrm{N}$ & $27: 1$ & - \\
\hline 4 & Temperature in the thermophilic phase & $64^{\circ} \mathrm{C}$ & $34^{\circ} \mathrm{C}$ \\
\hline 5 & Temperature in the mesophilic phase & $29^{\circ} \mathrm{C}$ & $27^{\circ} \mathrm{C}$ \\
\hline 6 & Aeration speed & $4,8 \mathrm{dm}^{3} / \mathrm{min}^{-1}$ & $4,2 \mathrm{dm}^{3} / \mathrm{min}$ \\
\hline 7 & Ambient temperature & $24-27^{\circ} \mathrm{C}$ & $24-27^{\circ} \mathrm{C}$ \\
\hline
\end{tabular}




\section{Characteristics of biofilter}

The biofilter was installed behind the last unit of the container bioreactor. It consisted of a casing and a layer of filtering material filled with it, settled by microorganisms adapted to the distribution of impurities. The biofilter volume was $12 \mathrm{~m}^{3}$. The analysis of the purification level was carried out after 6 months from commissioning. The biofilter filling was a mixture of peat, wood chips and coconut chips. Contaminated gases from the bioreactor system were fed from the bottom to the biofilter (Figure 1).

The installed ball valves allowed gas uptake before and after the biofilter in order to determine the efficiency of its operation. In the solution used, it is possible to return the condensate accumulated on the walls of the biofilter. It can be used to re-sprinkle the deposit. The second figure presents a schematic diagram of biofilter connection for induction of bioreactors.

\section{The signs used}

The portable GA biogas analyzer series GA 5000 certified ATEX II $2 \mathrm{G}$ Ex ib IIA T1 Gb $\left(\mathrm{Ta}=-10^{\circ} \mathrm{C}\right.$ to $\left.+50^{\circ} \mathrm{C}\right)$ IECEx, CSA was used for analyzing the gases generated during composting. The composition of the compost mixture was marked with dry mass and losses on ignition (PN - EN 12879 and PN - EN 128800).

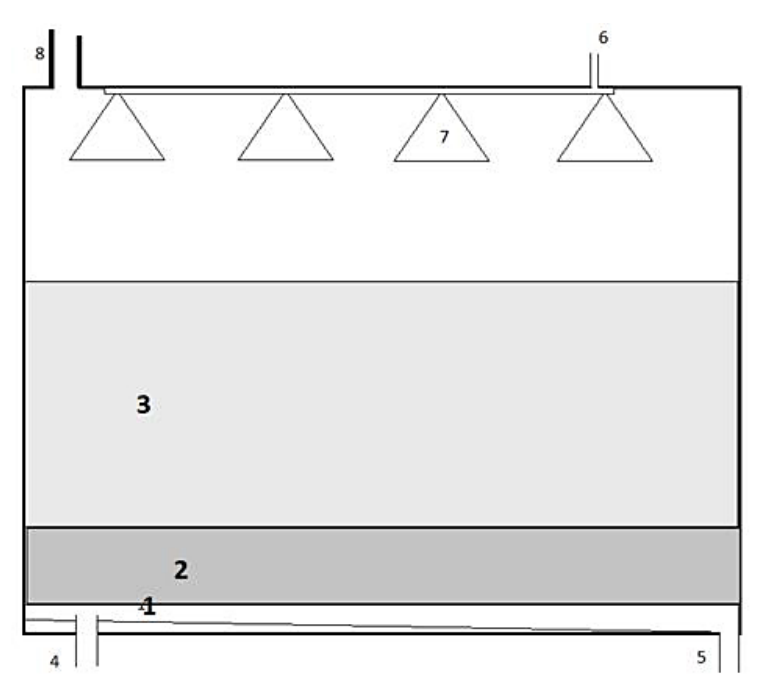

Fig. 1. A schematic cross-section of a biofilter: 1 - perforated bed base; 2 - filling with coarse wood chips; 3 - mixed filling (peat, chips, chips); 4 - biogas supply; 5 - condensate drainage; 6 bringing condensate to the sprinklers; 7 - nozzles for spraying sprinklers; 8 - air outlet fireplace
The content of total nitrogen (PN - EN 12176), general phosphorus (PN - EN 14672) and general carbon in compost were also determined using the TOC Multi N / C 2100 analyzer.

\section{DISCUSSING THE RESEARCH RESULTS}

The optimal temperature range in the biofilter is $25-33^{\circ} \mathrm{C}$. In winter, the temperature inside the biofilters is higher than the ambient temperature by $10-20^{\circ} \mathrm{C}$. This is due to the fact that large amounts of heat are released in microbiological processes. In addition, the composting process itself is a high-temperature process, especially during the first 14 days. When conducting the process in the summer at high temperature, the moisture content of the biofilter should be carefully controlled and sprayed as required. During the experiment, continuous monitoring of temperature changes was carried out. For most bacteria, $\mathrm{pH} 7.0-7.5$ is the optimal value. A drop in $\mathrm{pH}$ below 4 and an increase to more than 11, results in a significant reduction in bacterial activity, as well as frequent and rapid changes in the $\mathrm{pH}$ of the environment. It was found that in the conducted pilot studies, the $\mathrm{pH}$ did not change rapidly and remained in the range of 5.8-7.5. The tests used and compared the results obtained before and after the biogas passed through the bed. Gas analysis showed a significant reduction in odor compounds $[12,13]$. Due to the summer period and the ambient temperature fluctuating in the range of $21-30^{\circ} \mathrm{C}$, such a small temperature range was found to have a very small influence on the changes in the quality of off-gases. The bottom layer of the biofilter was filled with a thicker filter material in the form of wood chips. This was the first stage of adaptation of the purified biogas. The quality of the filter material also influences the development of the biofilter. Inoculated microbiological analyses showed that on the surface of peat biofilm development occurs faster than in the case of sawdust. Biodiversity of nutrients contained in peat positively influenced the rate of colonization of the deposit. The time of biogas flow through the bed was determined by forced air circulation.

The table presents the emission level of hydrogen sulphide and ammonia immediately after leaving the biofilter in the thermophilic, mesophilic phase and after applying the filtration.

According to the analysis of the results, both the emission level and the degree of removal depend 
on the temperature, and thus also on the phase of the composting process. Pagnas and Sanches showed a similar dependence in their study. Composted waste was of animal origin. However, in both experiments, a change in reduction levels was noted along with a phase change. It is also important to change the $\mathrm{pH}$ of the compost mixture [17].

The research shows that the use of biofiltration in technological processes is associated with a number of benefits, at the same time, it is a simple method and does not require excessive financial outlays. Due to the fact that odors are not only hydrogen sulphide and ammonia, the research assumes further analysis and selection of the deposit for optimization of the process.

Industrial waste deodorization equipment used industrially was already employed in the 1960s. Originally, biofiltration of air through a layer of fluffed soil was used, later replaced by compost or peat (similar as in the experiment described above). This method of air purification is used with high efficiency in many waste management plants. However, the research into the intensification and modernization process of the used biofilters is still ongoing.

In the research conducted by Park et al., biofiltration was used to remove the ammonia produced during composting of dairy waste. Biofilters were used, among others filled with compost, operating at a temperature of $15-20^{\circ} \mathrm{C}$. As in the case of the described experiment, the biofilter neutralized over $90 \%$ of the ammonia produced during composting [18].

\section{CONCLUSIONS}

Composting deals with the processing of waste and sludge originating, among others, from agricultural and horticultural farms, agro-food processing, processing of natural fibers, selective collection of biodegradable waste in cities, biological wastewater treatment and from the care of urban greenery. Using the composting technology, which consists in partial humification (partial distribution of primary organic compounds with secondary synthesis) and biomass mineralization, a compost with significant fertilizing effect is produced. The use of composting allows the return of organic matter to the environment. The sources of odor nuisance may arise at the stage of: waste overloading ; storage bunker; movement of the batch; composting hall; storage tanks for liquid organic waste; moisturizing the active biological material; and surface emission from freshly converted piles.

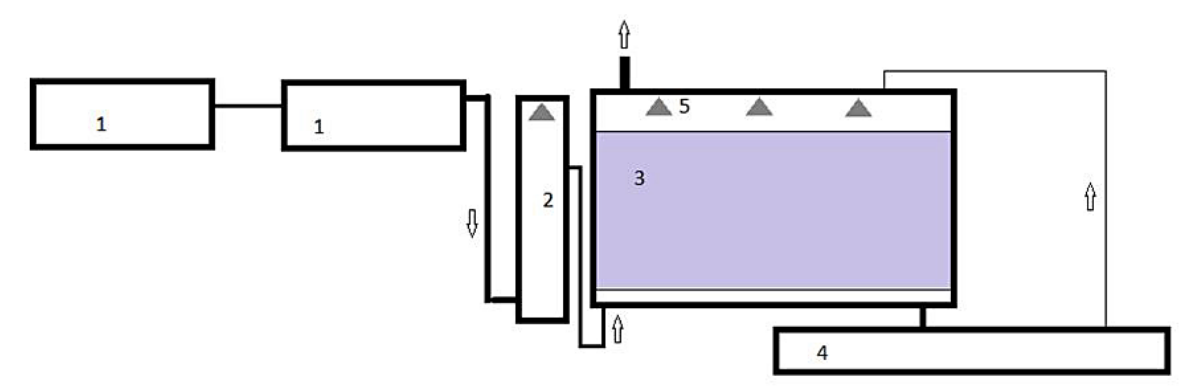

Fig. 2. The layout scheme used in the experiment: 1 - bioreactor module, 2 - biogas spray chamber, 3 - biofilter with bed, 4 - condensate tank, 5 - spray nozzles.

The arrows indicate the direction of the process

Table 2. Effectiveness of odorous compounds removal using a biofilter

\begin{tabular}{|c|c|c|c|c|c|}
\hline Compound & Composting phase & Unit & Value before biofilter & Value after biofilter & Reduction [\%] \\
\hline $\mathrm{NH}_{3}$ & termophilic & $\mathrm{mg} / \mathrm{m}^{3}$ & 286 & 32 & 89 \\
\hline $\mathrm{NH}_{3}$ & mezophilic & $\mathrm{mg} / \mathrm{m}^{3}$ & 247 & 40 & 84 \\
\hline $\mathrm{NH}_{3}$ & psychrophilic & $\mathrm{mg} / \mathrm{m}^{3}$ & 239 & 22 & 91 \\
\hline $\mathrm{NH}_{3}$ & after averaging & $\mathrm{mg} / \mathrm{m}^{3}$ & 257 & 31 & 88 \\
\hline $\mathrm{H}_{2} \mathrm{~S}$ & termophilic & $\mathrm{mg} / \mathrm{m}^{3}$ & 647 & 19 & 97 \\
\hline $\mathrm{H}_{2} \mathrm{~S}$ & mezophilic & $\mathrm{mg} / \mathrm{m}^{3}$ & 630 & 37 & 94 \\
\hline $\mathrm{H}_{2} \mathrm{~S}$ & psychrophilic & $\mathrm{mg} / \mathrm{m}^{3}$ & 625 & 29 & 98 \\
\hline $\mathrm{H}_{2} \mathrm{~S}$ & after averaging & $\mathrm{mg} / \mathrm{m}^{3}$ & 634 & & 96 \\
\hline
\end{tabular}


However, biofiltration is an effective reduction of odor nuisance classified as ecological and non-waste technique. It is becoming more and more popular due to its simplicity as well as low investment and operating costs, with the simultaneous possibility of achieving high cleaning efficiency. Appropriate selection of device parameters and proper operation are important aspects. These are the factors conditioning efficient operation. The conducted research indicates that biofiltration is an effective method of waste gases purification. The level of effectiveness of gas treatment depends on the substances contained in it and ranges from 40 to $100 \%$. An important factor related to the proper functioning of biofilters is to ensure optimal conditions for the development and activity of microorganisms. Providing specific conditions regarding such parameters as temperature and humidity, affects the efficiency and stability of the biofiter operation and increase the efficiency of purification of gases from odorogenic compounds.

\section{Acknowledgements}

Publication supported by the Polish Ministry of Science and Higher Education as a part of the program of activities disseminating science from the project „Organization of the First International Science Conference - Ecological and Environmental Engineering", 26-29 June 2018, Kraków.

The research was carried out under BS/ PB-401-301/11/6.

\section{REFERENCES}

1. Szklarczyk M., 1991. Biologiczne oczyszczanie gazów odlotowych. Wrocław: Wydawnictwo Politechniki Wrocławskiej.

2. Wierzbińska M. 2010. Zastosowanie metod biofiltracji do dezodoryzacji gazów odlotowych przy wykorzystaniu złóż włóknistych. cz. II - Czynniki warunkujące optymalizację procesu biofiltracji. Ochrona powietrza i problemy odpadów.

3. Kwarciak-Kozłowska A., Bańka B. 2014. Biofiltracja jako metoda unieszkodliwiania odorów powstających podczas procesów przemiany materii organicznej. Inżynieria i Ochrona Środowiska, 17(4), 625-639
4. Adamiak W., Kita U., Sówka I., Szklarczyk M. 2012. Rola selekcji mikroorganizmów w procesie biodegradacji benzene. Przemysł Chemiczny, 91(5), 655-659.

5. Van Groenestijn J.W., Kraakman N.J.R. 2005. Recent developments in biological waste gas purification in Europe. Chemical Engineering Journal, 113(2), 85-91.

6. Kapusta K. 2007. Ochrona zapachowej jakości powietrza. Doświadczenia światowe w świetle potrzeby unormowań prawnych w Polsce. Prace Naukowe GIG, 31-50.

7. Burgess J.E., Parson S.A., Stuetz R.M. 2001. Developments in odour control and waste gas treatment biotechnology: a review. Biotechnology Advances, 11(1), 35-63.

8. McNevin D., Barford J., 2000. Biofiltration as an odour abatement strategy. Biochemical Engineering Journal, 5(3): 231-242. Ramirez, A., GarciaAguilar, B. Jones, P., Heitz M. (2012). Improvement of methane biofiltration by the addition of non-ionic surfactants to biofilters packed with inert materials. Process Biochemistry, 47(1), 76-82.

9. Sówka I., Zwoździak P, Zwoździak A., Zwoździak J. 2008. Problemy uciążliwości zapachowej wybranych obiektów gospodarki komunalnej. Ekotoksykologia w OchronieŚrodowiska,409-414.

10. Ulfik K. 2010. Biofiltracja lotnych związków organicznych za pomocą bakterii i grzybów mikroskopowych.

11. Sówka I., 2011. Metody identyfikacji odorotwórczych gazów emitowanych $\mathrm{z}$ obiektów przemysłowych, Wrocław: Oficyna wydawnicza Politechniki Wrocławskiej.

12. SówkaI.,MillerU.,SobczyńskiP.2014.Emisjaodorów z procesów kompostowania odpadów komunalnych. Przemysł Chemiczny 1, 93(15), 1000-1003.

13. Szynkowska M.I.,Zwożdzak J., 2010. Współczesna problematyka odorów. WNT Warszawa.

14. Wieczorek, A. 1998. Wpływ emisji lotnych związków organicznych na zapach gazów odlotowych z kompostowni odpadów. Ochrona Środowiska, 1(68), 33-35.

15. Dz. U. z 2013 r. poz. 21.

16. Pagans E., Font X., Sánchez A., 2005. Biofiltration for ammonia removal from composting exhaust gases, Chemical Engineering Journal, 113, 105-110.

17. Hong J.H., Park K.J., 2005. Compost biofiltration of ammonia gas from bin composting, Bioresource Technology, 96, 741-745. 